\title{
Estimation of biochemical factors responsible for resistance to root and collar rot (Macrophomina phaseolina (Tassi) Goid.) in okra
}

\section{T. Aravind*}

Department of Plant Pathology, G. B. Pant University of Agriculture and Technology, Pantnagar -263145 (Uttarakhand), India

\section{A. B. Brahmbhatt}

Department of Plant Pathology, B. A. College of Agriculture, Anand Agricultural University, Anand- 388110 (Gujarat), India

${ }^{*}$ Corresponding author. E-mail: aravindtherthala@gmail.com

\begin{abstract}
Twenty okra genotypes were screened for their resistance to root and collar rot incited by Macrophomina phaseolina in the experimental fields of Department of Plant Pathology, B. A. College of Agriculture, Anand Agricultural University. Based on their disease reaction, they were grouped into four categories i.e., resistant, moderately resistant, susceptible and highly susceptible. The biochemical analysis of the resistant and susceptible genotypes revealed that the total soluble sugar, reducing sugar and non reducing sugar decreased following inoculation by the pathogen. The decrease in total soluble sugar, reducing sugar and non reducing sugar were 21.54, 21.73 and 21.42 per cent in resistant variety, whereas in highly susceptible variety it was $6.06,6.10$ and 3.03 per cent, respectively. The total phenol content, soluble protein and peroxidase activity increased on inoculation with the pathogen. In the resistant variety, the increase in phenol content, soluble protein and peroxidase activity was $23.4,32.56$ and 63.86 per cent whereas in moderately resistant variety this was $19.85,21.63$ and 55.29 per cent, respectively. Susceptible and highly susceptible genotypes had low to moderate increase in the three parameters. The experimental results confirmed the importance of these biochemical factors in imparting the host resistance to root and collar rot.
\end{abstract}

Keywords: Okra, Macrophomina phaseolina, Phenol, Sugar, Protein, Peroxidase

\section{INTRODUCTION}

Okra (Abelmoshus esculentus (L.) Moench) is an important annual vegetable belonging to Malvacea family. Okra is known by different names viz., ladies finger, bhindi, bamia, okro or gumbo in different parts of the world. It is mainly grown in India, Nigeria, Sudan, Pakistan, Ghana, Egypt, Saudi Arabia, Mexico and Cameroon. India rank first in area and production followed by Nigeria. In India, it is grown in an area of 0.528 million ha with an annual production of 6.14 million tonnes. West Bengal is the leading producer followed by Gujarat (Anonymous, 2017). There is a great scope of increasing the okra production in the country, but some biotic factors like diseases hamper the successful cultivation. The major diseases affecting the crop include yellow vein mosaic, powdery mildew, Cercospora leaf spot, etc. Root and collar rot incited by $M$. phaseolina is emerging as a major threat to okra cultivation especially in areas having low rainfall and prolonged dry spell. Macrophomina

\section{Article Info}

DOI: 10.31018/jans.v10i4.1936 Received: October 27, 2018 Revised: November 19, 2018 Accepted: November 26, 2018

\section{How to Cite}

Aravind, T. and Brahmbhatt, A.B. (2018). Estimation of biochemical factors responsible for resistance to root and collar rot (Macrophomina phaseolina (Tassi) Goid.) in okra. Journal of Applied and Natural Science, 10 (4): $1266-1270$ phaseolina is one of the most damaging primarily soil borne pathogens having heterogeneous host specificity. It infects about 500 plant species in more than 100 families throughout the world (Singh et al., 1990). The present study was undertaken to evaluate the biochemical factors like total soluble sugar, total phenol, soluble proteins and peroxidase responsible for imparting resistance to root and collar rot in okra against $M$. phaseolina. This would help in further validation of field generated data on disease resistance of different okra genotypes. Resistant germplasm may further be used in breeding programmes for development of disease resistant commercial cultivars.

\section{MATERIALS AND METHODS}

Twenty okra genotypes were screened for resistance to root and collar rot incited by Macrophomina phaseolina for two seasons (Summer and Kharif, 2016) at the experimental field of Department of Pathology, B. A. College of Agriculture, Anand Agriculture University, Anand. 
Based on the disease reactions, the genotypes were categorized into resistant, moderately resistant, moderately susceptible and susceptible as per Raj and Prasad (1975). One genotype from each category [(AOL-15-23- Resistant; AOL15-21- Moderately resistant; AOL-13-96Susceptible; AOL-12-55- Highly susceptible)] were selected for biochemical analysis and two replications were maintained for each genotype. The okra plants for the biochemical tests were raised in the pots contaminated with the pathogen mass multiplied in sand-maize medium. Collar portion from 30 days old seedlings was used for the various assays.

Total soluble sugar: Total soluble sugars from the resistant and susceptible okra varieties were determined by phenol sulphuric acid method as described by Bhatnagar et. al. (2005). Two hundred mg sample was digested in five $\mathrm{ml} 80$ per cent alcohol and incubated for two hours on shaker. Then it was centrifuged and $1 \mathrm{ml}$ of the clear solution was taken in test tube and evaporated to dryness in boiling water bath. One $\mathrm{ml}$ distilled water was added and used as sample. Working standards $(0.2,0.4,0.6,0.8$ and $1 \mathrm{ml})$ were pipetted into series of test tubes. 0.1 and 0.2 $\mathrm{ml}$ of the sample solution was pippeted into two separate test tubes and volume was made upto 1 $\mathrm{ml}$ with distilled water. A blank of $1 \mathrm{ml}$ of distill water was also prepared. Then one $\mathrm{ml}$ of phenol was added to each test tube followed by five $\mathrm{ml}$ 96 per cent sulphuric acid to each test tube and shaken well for $10 \mathrm{~min}$. The test tubes were then placed in a water bath at $25-30^{\circ} \mathrm{C}$ for $20 \mathrm{~min}$. The colour development was measured at $490 \mathrm{~nm}$. TSS present in the samples were calculated from the standard graph.

Reducing sugars: Reducing sugars of plant samples was estimated by Nelson's modification of Somogyi's method (Nelson, 1944). Hundred mg sample was weighed and sugars were extracted with hot 80 per cent ethanol twice $(5 \mathrm{ml}$ each time). Supernatant was collected and evaporated by keeping over water bath at $80^{\circ} \mathrm{C} .10 \mathrm{ml}$ water was added to dissolve the sugars. 0.1 and $0.2 \mathrm{ml}$ of the aliquot and working standard $(0.2,0.4,0.6$, 0.8 and $1 \mathrm{ml}$ ) were pippeted into test tubes and volume was made up to two $\mathrm{ml}$ with distilled water. Two $\mathrm{ml}$ distilled water served as blank. One $\mathrm{ml}$ of alkaline copper tartrate was added into each tube and kept in boiling water for $10 \mathrm{~min}$. One $\mathrm{ml}$ of arsenomolybdate acid reagent was added to test tubes after cooling. The volume of the test tubes were made up to $10 \mathrm{ml}$ and absorbance was measured at $620 \mathrm{~nm}$ after $10 \mathrm{~min}$. The amount of reducing sugar was calculated from standard graph.The results were expressed as $\mathrm{mg} / \mathrm{g}$ fresh weight.

Total phenol content: Total phenol content from the resistant and susceptible okra plants was estimated by Folin ciocalteau method as described by Malik and Singh (1980). The dilute extracts of different concentrations were taken in $10 \mathrm{ml}$ glass tubes and total volume made to three $\mathrm{ml}$ with distilled water. These were then mixed with $0.5 \mathrm{ml}$ Folin - Ciocalteau reagent (1:1 with water) and $2 \mathrm{ml} \mathrm{Na} \mathrm{CO}_{3}(20 \%)$. The tubes containing the blue solutions were warmed for one minute, cooled and absorbance was measured at $650 \mathrm{~nm}$ against the reagent blank. The standard curve was prepared using known concentrations of catechol at $650 \mathrm{~nm}$. The total phenol content in the test samples was calculated from the standard curve and expressed as $\mathrm{mg} / \mathrm{g}$ fresh weight.

Soluble protein: Soluble protein was estimated using Lowry method (Lowry et al. 1951). Forty mg collar region of okra plants were weighed and transferred to a digestion flask. One gram catalyst mixture and two $\mathrm{ml}$ concentrated sulphuric acid were added and the mixture was digested until the solution turn colourless (approx. $40 \mathrm{~min}$. at 370 ${ }^{\circ} \mathrm{C}$ ). After cooling minimum quantity of water was added to dissolve the solids and allowed to cool. Ten $\mathrm{ml}$ of boric acid was pipetted into $100 \mathrm{ml}$ Erlenmeyer flask and two to three drops of the indicator was added. The flask was then placed under the condenser extending below the surface of the solution. The digest was transferred to distillation apparatus and the flask was rinsed four times with two to three $\mathrm{ml}$ of distilled water. Ten $\mathrm{ml}$ of sodium hydroxide-sodium thiosulphate solution was added to still and stem distilled until $20 \mathrm{ml}$ of distillate collected (20 min.). The receiving flask was lowered and distillation was continued for one more time tip of the condenser was washed with few of drops water and receiving flask was lowered. The contents of the receiving flask were titrated to grey endpoint/ first appearance of violet colour. A blank titration was determined (without sample) using the same quantity of reagents and same digestion and distillation period as for sample determination. A standard check of tyrosine was also made $(10 \mathrm{mg} / \mathrm{l})$.

Percentage of nitrogen $(\% \mathrm{~N})=(\mathrm{ml}$ of $\mathrm{HCl}$ in determination - ml blank) x normality x $100 \times$ $14.007 / \mathrm{mg}$ sample $\quad$....Eq.1 Protein $(\%) \quad=\% \mathrm{~N} \times 6.25 \quad \ldots$. Eq. 2 Peroxidase: The peroxidase activity was estimated as per the method suggested by Costa et al. (2002). Exactly, $300 \mathrm{mg}$ of plant tissue was taken and homogenised with one $\mathrm{ml}$ of protein extraction buffer (SDS $0.02 \%$, Tris buffer $0.5 \mathrm{M}$ and $\beta$-Mercaptoethanol $1 \%$ ) and vortexed in two $\mathrm{ml}$ centrifuge tubes. These samples were centrifuged at 13,000 rpm for 10 minutes. Clear supernatant was collected and used for analysis. The reaction mixture contained $2.90 \mathrm{ml}$ of 0.03 per cent $\mathrm{H}_{2} \mathrm{O}_{2}$ (substrate) in $0.01 \mathrm{M}$ phosphate buffer (pH 6.0), $25 \mu \mathrm{l}$ of one per cent ortho-dianisidine in methanol and $100 \mu \mathrm{l}$ of enzyme extract. The 
reaction was initiated by adding the enzyme. The change in colour of oxidized dye was read at 460 $\mathrm{nm}$ up to three minutes, at an interval of 15 seconds. Blank was run without the addition of substrate. The enzyme activity was expressed as change in OD/min/fresh tissue.

\section{RESULTS AND DISCUSSION}

Total soluble sugar, total phenol content, soluble protein and peroxidase activity was determined before and six days after the inoculation by the pathogen and results are presented in table 1 and 2 .

Total soluble sugar: The total soluble sugar was found to be high in the resistant genotype followed by the moderately resistant ones. Total soluble sugar before inoculation by the pathogen was found in range of $2.59 \mathrm{mg} / \mathrm{g}$ in highly susceptible genotype (AOL-12-55) to $6.64 \mathrm{mg} / \mathrm{g}$ in resistant genotype (AOL-15-23). The moderately resistant (AOL-15-21) and susceptible genotype (AOL-1396) had TSS of 5.41 and $3.78 \mathrm{mg} / \mathrm{g}$ respectively. After inoculation with the pathogen, the TSS was found to decrease in all the genotypes with highest percentage decrease recorded in the resistant genotype $(21.54 \%)$ followed by the moderately resistant genotype $(17.71 \%)$. In susceptible and highly susceptible genotype TSS decreased by 13.41 and 6.06 per cent respectively.

The reducing and non reducing sugar also had a similar trend as that of total soluble sugar. Reducing sugar was found to be highest in resistant genotype both before $(2.58 \mathrm{mg} / \mathrm{g})$ and after $(2.03 \mathrm{mg} / \mathrm{g}$ ) inoculation and showed a reduction by 21.73 per cent. Initial reducing sugar content in moderately resistant, susceptible and highly susceptible genotypes were $2.04,1.45$ and $1.20 \mathrm{mg} / \mathrm{g}$ which decreased by $15.57,12.05$ and 6.10 per cent, respectively after inoculation.

Non reducing sugar content in the plants was found to be higher than reducing sugar content. The non reducing sugar content in resistant geno- type decreased from 4.04 to $3.18 \mathrm{mg} / \mathrm{g}(21.42 \%)$ after inoculation by the pathogen. The non reducing sugar content decreased by $19.01,14.25$ and 6.03 per cent in moderately resistant, susceptible and highly susceptible genotypes, respectively. The decrease in sugar content after inoculation by pathogen may be attributed to increased respiration which leads to breakdown of sugar for the synthesis of defence related compounds like proteins and phenols. Since the respiration increase at a higher rate in the resistant genotype than the susceptible genotype the decrease in sugar content is high in resistant genotype compared to susceptible ones.

The similar conclusion were reported by El- Fikri et al. (2004) who reported that the sesamum varieties resistant to charcoal rot had higher soluble sugar content $(3.22-8.38 \%)$ compared to the susceptible varieties (1.18-3.97\%). Sandhu et al. (1998) has reported that the total soluble sugar and reducing sugar content decreased upon infection by the pathogen. According to Shahabuddhin and Anwar (1992) there was a decrease in total sugar and reducing sugar in jute following inoculation with $M$. phaseolina. Patil et al. (1985) reported that in tolerant genotypes the sugar level was two to three times higher than the susceptible ones.

Total phenol content: The total phenol content was found to be higher in the resistant genotype followed by the moderately resistant ones and increased upon inoculation with the pathogen (Table 2). In the resistant genotype, the total phenolics increased by 23.40 per cent from $1.41 \mathrm{mg} / \mathrm{g}$ in control plants to $1.74 \mathrm{mg} / \mathrm{g}$ after inoculation with the pathogen. The second highest percentage increase of total phenolics was recorded in the moderately resistant genotype (19.85\%). The susceptible and highly susceptible genotypes had only a minor increase in total phenol content viz., 8.62 and 5.68 per cent respectively.

Phenolics are major antifungal and antibacterial defence molecule in many plant species including

Table 1. Effect of $M$. phaseolina infection on total soluble sugar, reducing sugar and non reducing sugar.

\begin{tabular}{|c|c|c|c|c|c|c|c|c|c|}
\hline \multirow[b]{2}{*}{$\begin{array}{l}\text { Disease } \\
\text { Reaction }\end{array}$} & \multicolumn{3}{|c|}{ Before Inoculation $(\mathrm{mg} / \mathrm{g})$} & \multicolumn{2}{|c|}{ After Inoculation (mg/g) } & \multicolumn{3}{|c|}{ Decrease (\%) } & \multirow[b]{2}{*}{$\begin{array}{l}\text { Non Re- } \\
\text { ducing } \\
\text { Sugar }\end{array}$} \\
\hline & $\begin{array}{c}\text { Total } \\
\text { Soluble } \\
\text { Sugar }\end{array}$ & $\begin{array}{l}\text { Reduc- } \\
\text { ing } \\
\text { Sugar }\end{array}$ & $\begin{array}{l}\text { Non Re- } \\
\text { ducing } \\
\text { Sugar }\end{array}$ & $\begin{array}{c}\text { Total } \\
\text { Soluble } \\
\text { Sugar }\end{array}$ & $\begin{array}{l}\text { Reducing } \\
\text { Sugar }\end{array}$ & $\begin{array}{l}\text { Non Re- } \\
\text { ducing } \\
\text { Sugar }\end{array}$ & $\begin{array}{l}\text { Total Solu- } \\
\text { ble Sugar }\end{array}$ & $\begin{array}{l}\text { Reduc- } \\
\text { ing } \\
\text { Sugar }\end{array}$ & \\
\hline Resistant & 6.64 & 2.58 & 4.04 & 5.21 & 2.03 & 3.18 & 21.54 & 21.73 & 21.42 \\
\hline $\begin{array}{l}\text { Moderately } \\
\text { Resistant }\end{array}$ & 5.41 & 2.04 & 3.36 & 4.45 & 1.73 & 3.36 & 17.71 & 15.57 & 19.01 \\
\hline Susceptible & 3.78 & 1.45 & 2.33 & 3.27 & 1.28 & 2.33 & 13.41 & 12.05 & 14.25 \\
\hline $\begin{array}{l}\text { Highly Sus- } \\
\text { ceptible }\end{array}$ & 2.59 & 1.20 & 1.39 & 2.43 & 1.13 & 1.31 & 6.06 & 6.10 & 6.03 \\
\hline
\end{tabular}

Table 2. Effect of M. phaseolina infection on total phenol, soluble protein and peroxidase activity

\begin{tabular}{|c|c|c|c|c|c|c|c|c|c|}
\hline \multirow[b]{2}{*}{ Disease Reaction } & \multicolumn{3}{|c|}{ Before Inoculation } & \multicolumn{3}{|c|}{ After Inoculation } & \multicolumn{3}{|c|}{ Increase (\%) } \\
\hline & $\begin{array}{c}\text { Phe- } \\
\text { nol } \\
(\mathrm{mg} / \mathrm{g})\end{array}$ & $\begin{array}{l}\text { Protein } \\
(\%)\end{array}$ & $\begin{array}{c}\text { Peroxidase } \\
\text { ( } \Delta \text { OD/min/g of } \\
\text { fresh tissue) }\end{array}$ & $\begin{array}{l}\text { Phenol } \\
\text { (mg/g) }\end{array}$ & $\begin{array}{l}\text { Protein } \\
(\%)\end{array}$ & $\begin{array}{c}\text { Peroxidase } \\
\text { ( } \Delta \text { OD/min/g of } \\
\text { fresh tissue) }\end{array}$ & Phenol & Protein & $\begin{array}{c}\text { Peroxi- } \\
\text { dase }\end{array}$ \\
\hline Resistant & 1.41 & 6.35 & 2.83 & 1.74 & 9.41 & 4.64 & 23.40 & 32.56 & 63.86 \\
\hline $\begin{array}{l}\text { Moderately } \mathrm{Re}- \\
\text { sistant }\end{array}$ & 1.24 & 5.47 & 2.77 & 1.49 & 6.98 & 4.30 & 19.85 & 21.63 & 55.29 \\
\hline Susceptible & 1.08 & 5.03 & 2.48 & 1.17 & 5.58 & 3.35 & 8.62 & 9.80 & 34.79 \\
\hline Highly Susceptible & 1.01 & 4.37 & 2.46 & 1.06 & 4.59 & 3.25 & 5.68 & 4.76 & 32.07 \\
\hline
\end{tabular}


okra. Many of the phenolics are directly toxic to the pathogens, while others strengthen the cell wall and resist the hydrolytic enzymes of the pathogen (Singh, 2009). The results of the present study futher signifies importance of faster accumulation of phenolics in imparting resistance to the pathogen in the resistant genotype.

Kumari et al. (2015) has reported a positive correlation between polyphenol content and resistance to the charcoal rot resistance in sorghum cultivars. Similarly, Doley and Jite (2013) has reported an increase in total phenolics in groundnut plants upon infection with $M$. phaseolina. According to the report of Sharma (2011), Macrophomina infection induced a significant increase in the polyphenols, polyphenol oxidases and PAL activity in resistant sesamum cultivars. Similar conclusions on increase in polyphenol content in jute upon infection by Macrophomina were made by Shahabuddhin and Anwar (1992).

Soluble protein: The soluble protein content in the uninoculated plants ranged from 4.37 per cent in highly susceptible genotype to 6.35 per cent resistant genotype. After inoculation with the pathogen, there was an increase in protein content by $32.56,21.63,9.80$ and 4.76 per cent in resistant, moderately resistant, susceptible and highly susceptible genotypes respectively. In resistant genotype the protein content rose from 6.35 to 9.41 per cent whereas in moderately resistant genotype it rose from 5.47 to 6.98 per cent. The susceptible and highly susceptible genotypes recorded only minor increase of 9.80 and 4.76 per cent respectively.

The different types of protein play a major role in defence mechanisms of plant. It may be due to this reason that there was an increase in protein content in the infected plants. Since the respiration and synthesis of defence related metabolites in resistant varieties rise rapidly, there is a faster accumulation of protein and thereby increase in protein percentage in plant system following infection by the pathogen.

Kaur et al. (2008) has reported that the protein content in maize cultivars moderately resistant to charcoal rot was higher (10.78\%) compared to the moderately susceptible cultivars (10.19\%). According to Doley and Jite (2013) the protein content in the groundnut plants inoculated with Macrophomina was higher compared to the control plants. Sharma (2011) has reported an increase in all defence related protein in sesamum to varying levels of infection by $M$. phaseolina.

Peroxidase: Initially the peroxidase activity was 2.83 in resistant genotype while it was 2.46 in the highly susceptible genotype and it increased after inoculation. The activity in susceptible and moderately resistant genotypes ranged from 2.48 to 2.77 units. The increase in activity was highest in case of resistant varieties i.e. 63.86 percent followed by the moderately resistant genotype (55.29\%). In susceptible genotype, the activity increased from 2.48 to 3.35 i.e. by 34.79 per cent, whereas this increase was only 32.07 per cent in highly susceptible genotype.

Peroxidase is one of the key enzymes in plant defence mechanisms. It breaks down the hydrogen peroxide in plant system and the increase in peroxidase activity positively correlated to the level of disease resistance in plants. Kumari et al. (2015) has reported higher peroxidase activity in cultivars of sorghum resistant to charcoal rot thereby sustaining leser oxidative damage. According to Abhoshasha et al. (2008) the inoculation of sunflower with $M$. phaseolina resulted in a higher peroxidase activity in the resistant cultivars. Ashraf et al. (2005) has reported that in chickpea, infection with $M$. phaseolina increased the peroxidase activity and this increase was highest in the resistant varieties $(45.24 \%)$ followed by the moderately resistant varieties (39.62-42.52\%). While in susceptible increase was only 13.51 to 25.54 per cent over control.

\section{Conclusion}

It can be concluded that the various biochemical parameters namely sugar, soluble protein, total phenol and peroxidase activity play a major role in host resistance against $M$. phaseolina in okra. Moreover, these biochemical parameters will help us in further validation of field generated data on evaluation of disease resistance various pests and diseases. However, more detailed investigation on the exact role played by these biomolecules in the host resistance would help us in manipulating them for improving the crop resistance to various biotic agents. The genotypes (AOL-15-23 \& AOL-15-21) which showed resistant/ moderately resistant reaction may be used for breeding programmes for the development of disease resistant commercial cultivars to effectively tackle the root and collar rot of okra.

\section{REFERENCES}

1. Abhoshosha, S. S., Alla, S. S. A., EL- Korany, A. E. and El- Argawy, E. (2008). Protein analysis and peroxidase isozymes as molecular markers for resistance and susceptibility of sunflower to Macrophomina phaseolina. Int. J. Agri. Biol., 10(1): 28 -34. DOI: 07-114/AKP/2008/10-1-28-34

2. Anonymous. 2017. Horticultural statistics at a glance (2017) Retreived from http://nhb.gov.in

3. Ashraf, M. S., Khan, T. A. and Hasan, S. (2005). Reaction of chickpea varieties to Macrophomina phaseolina and their effect on peroxidase activity. Pak. J. Bot., 37 (3):761-767.

4. Bhatnagar, R., Shukla, Y. M. and Talati, J. G. (2005). Biochemical methods for agricultural sciences. Anand Agricultural University, Department of Biochemistry. 
Anand.

5. Costa, H., Gallego, S. M. and Tomaro, M. L. (2002). Effect of UV-B radiation on antioxidant defense system in sunflower cotyledons. Plant Sci., 162: 939 - 945. PII: S 0168 - 9452 ( 02 ) 00051 - 1

6. Doley, K. and Jite, P. K. (2013). Disease management and biochemical changes in groundnut inoculated with Glomus facsiculatum and pathogenic Macrophomina phaseolina (Tassi.) Goidanch. Plant Sci. Feed, 3 (2): 21-26. URI: http:/l eprints.icrisat.ac.in/id/eprint/11585

7. El- Fikri, A. I. I., El-Deeb, A. A., Mohammed, F. G. and Khalifa, M. M. A. (2004). Controlling sesame charcoal rot incited by Macrophomina phaseolina under field conditions by using resistant cultivars and some seed and soil treatments. Egypt. J. Phytopathol., 32 (1):103-118

8. Kaur, H., Sharma, S. and Saxena, A. K. (2008). Biochemical indicators for resistance to charcoal and Fusarium stalk rot in maize hybrids. J. Res. Punjab Agricultural University, 45 (3): 117-120.

9. Kumari, N., Sharma, I., Alam, A. and Sharma, V. (2015). Screening of sorghum genotype and biochemical changes for resistance to damage by Macrophomina phaseolina. Arch. Phytopathol. Plant Protec., 9 (12): 760-775.

10.Lowry, O. H., Rosebrough, N. J., Farr, A. L. and Randall, R. J. (1951). Protein measurement with Folin phenol reagent. J. Biol. Chem., 2: 265-275.
11.Malik, E. P. and Singh, M. B. (1980). Plant Enzymology and Histoenzymology ( $1^{\text {st }}$ Edn.). Kalyani Publishers, New Delhi.

12.Nelson, N. (1944). A photometric adoption of Somogyis' method for determination of glucose. J. Biol. Chem., 153: 375-380.

13.Patil, S. H., Hedge, R. K. and Anahosur, K. H. (1985). Role of sugars and phenols in charcoal rot resistance of sorghum. J. Phytopathol., 113 (1): 3035. DOI: 10.1111/j.1439-0434.1985.tb00821.x.

14.Raj, S. A and Prasad, N. N. (1975). Reaction of groundnut to Rhizoctonia bataticola (Macrophomina phaseolina). Indian Phytopathol. 28: 440-441.

15.Sandhu, A., Singh, R. D., Kant, U. (1998). Changes in carbohydrate contents and hydrolyzing en-

zymes in cowpea infected by Macrophmina phaseolina. Ann. Arid Zone, 37 (4): 423-425.

16.Shahabuddhin, M. and Anwar, M. M. (1992). Metabolic changes in the jute plant due to fungal infection. Bangladesh J. Bot., 21: 206-212.

17.Sharma, A. (2011). Effect of Macrophomina phaseolina infection in Sesamum. Paper presented at the International Conference on Issues for Climate Change, Land Use Diversification and Biotechnological Tools for Livelihood Security.

18.Singh SK, Nene YL, Reddy MV. (1990). Influence of cropping systems on Macrophomina phaseolina population in soil. J. Plant Dis. 74: 812-814. DOI: 10.1094/PD-74-0812 